\title{
Kinerja Mesin Diesel Memakai Bahan Bakar Biodiesel Biji Karet dan Analisa Emisi Gas Buang
}

\author{
I Wayan Susila \\ Fakultas Teknik Universitas Negeri Surabaya, Surabaya \\ E-mail: wayansusila@yahoo.com
}

\begin{abstract}
ABSTRAK
Penelitian pengembangan proses produksi biodiesel (B-100) dari minyak biji karet atau rubber seed oil (RSO) yang diproduksi secara non-katalis superheated metanol di dalam sebuah bubble column reactor (BCR) tekanan atmosfir telah dilaporkan. Spesifikasi B-100 tersebut dipergunakan sebagai bahan bakar dalam penelitian ini yaitu: densitas $882 \mathrm{~g} / \mathrm{ml}$; viskositas kinematik 5,19 cSt; calculated cetane index (CCI) 47,5; titik tuang $-6^{\circ} \mathrm{C}$; flash point $200{ }^{\circ} \mathrm{C}$; residu karbon mikro dalam sampel asli $0,126 \%$ massa dan dalam $10 \%$ ampas distilasi 2,87\% massa; sedimen $0,01 \%$ volume; temperatur distilasi $347^{\circ} \mathrm{C}$; kandungan sulfur $0,72 \mathrm{ppm}$; angka asam 0,01 mgKOH/g; serta nilai kalor rendah 9184,43 kkal/kg. Biodiesel dicampur dengan solar (B-0) pada tingkat perbandingan tertentu sehingga diperoleh B-5, B-10, B-15, dan B-20 (B-5 adalah campuran antara biodiesel 5\% serta solar 95\%, dst) dipergunakan sebagai bahan bakar pada mesin diesel stasioner. Kinerja mesin diesel dan emisi gas buang dibandingkan dengan mesin yang memakai solar (B-0). Mesin dioperasikan pada putaran konstan 1350, 1750, 2150, 2550, dan $2950 \mathrm{rpm}$. Hasil penelitian menunjukkan bahwa bahan bakar B-10 menghasilkan kinerja mesin terbaik pada putaran $2550 \mathrm{rpm}$. Pada putaran ini diperoleh daya maksimum sebesar 36,95 PS, konsumsi bahan bakar spesifik terendah sebesar 0,256 kg/(PS.jam), efisiensi termal $58,44 \%$, kandungan CO terkecil sebesar 0,4\%, dan opasitas gas buang 58,6\% HSU memenuhi Peraturan Menteri Negara Lingkungan Hidup Nomor 5 tahun 2006, dan tidak perlu memodifikasi mesin. Jika dibandingkan dengan solar murni (B-0), B-10 lebih baik dari pada B-0 karena pada kondisi optimum menghasilkan kenaikan daya sebesar 1,8\%, konsumsi bahan bakar spesifik sama 0,256 kg/(PS.jam), efesiensi termal naik 2,4\%, kadar CO gas buang turun $80 \%$, serta $\mathrm{CO}_{2}$ turun $55 \%$.
\end{abstract}

Kata kunci: Biodiesel, RSO, non-katalis, mesin diesel.

\begin{abstract}
The research about development of biodiesel (B-100) production process from $R S O$ which is produced in the non-catalyst superheated methanol in a bubble column reactor (BCR) atmospheric pressure has been reported. The fuel which is used in this research has the following specifications: density $882 \mathrm{~g} / \mathrm{ml}$; kinematic viscosity $5.19 \mathrm{cSt}$; calculated cetane index (CCI), 47.5; pour point $-6^{\circ} \mathrm{C}$, flash point $200^{\circ} \mathrm{C}$; micro carbon residue in the original sample $0.126 \%$ of mass and the $10 \%$ distillation residue is $2.87 \%$ of mass; sediment $0.01 \%$ of volume; destilation temperature $347^{\circ} \mathrm{C}$; sulfur content $0.72 \mathrm{ppm}$; acid number $0.01 \mathrm{mgKOH} / \mathrm{g}$; and low heating value $9184.43 \mathrm{kcal} / \mathrm{kg}$. Biodiesel (B-100) was blended with diesel fuel (B-0) at a certain level of comparison in order to obtain B-5, B-10, B-15, and B-20 (B-5 is a mixture of 5\% biodiesel and $95 \%$ diesel fuel, and so on) and then it is used as fuel in diesel engine stationary. Engine performance and exhaust emissions are compared with engines that use diesel fuel (B-0). The machine is operated in constant rotation in $1350,1750,2150,2550$, and $2950 \mathrm{rpm}$. The results showed that $B-10$ produced the best engine performance at $2550 \mathrm{rpm}$. In this rotation, the maximum power obtained was $36.95 \mathrm{PS}$, the lowest specific fuel consumption was $0.256 \mathrm{~kg} /(P S . h r)$, the thermal efficiency $58.44 \%$, the lowest CO content $0.4 \%$, and flue gas opacity $58.6 \% \mathrm{HSU}$ in accordance with the State Minister of Environment Regulation Number 5/2006, and no modification of engine needed. Compared with diesel fuel (B-0), B-10 was better than B-O because it produced power increase $1.8 \%$, same specific fuel consumption $0.256 \mathrm{~kg} /(P S . h r)$, rising thermal efficiency $2.4 \%$, CO content decreased $80.0 \%$, and $\mathrm{CO}_{2}$ content decreased $55.0 \%$ at optimum condition.
\end{abstract}

Keywords: Biodiesel, RSO, non-catalyst, diesel engine. 


\section{PENDAHULUAN}

Proses pembuatan biodiesel dari bahan nabati pada umumnya dapat dibedakan menjadi dua cara yaitu: pertama metode katalis, menggunakan katalis (asam maupun basa) serta proses pencuciannya menggunakan air (wet wash system) atau absorban (dry wash system) berlangsung pada temperatur dan tekanan rendah; kedua, metode non-katalis dimana transesterfikasi berlangsung pada reaktor temperatur tinggi tekanan rendah atau tinggi. Tahapan proses yang dilalui pada metode katalis yaitu pengepresan atau ekstrak biji nabati sehingga diperoleh minyak biji karet atau disebut juga rubber seed oil (RSO), degumming (untuk mengikat lendir atau getah atau kotoran minyak mentah), esterifikasi (untuk menurunkan kadar asam lemak bebas atau FFA sampai di bawah 2,5\%), transesterifikasi (untuk memperoleh metil ester), pemisahan fatty acid methyl ester (FAME) dan gliserol, pencucian (basah atau kering), pemisahan lagi sehingga menghasilkan biodiesel siap dipasarkan.

Masalah utama yang dihadapi akibat pemakaian minyak nabati sebagai bahan bakar pada mesin diesel adalah rendahnya efesiensi termal dan tingginya opasitas gas buang jika dibandingkan dengan solar. "Road map" penelitian tentang kinerja mesin diesel dan analisis emisi gas buang mesin diesel yang menggunakan biodiesel dari berbagai bahan nabati seperti kelapa sawit, biji jarak, biji karet, bunga matahari, dll telah dilakukan oleh berbagai peneliti. Ramadhas dkk. [2], meneliti tentang karakteristik dan pengaruh pemakaian RSO sebagai bahan bakar pada mesin diesel. Bermacam-macam campuran biodiesel dari RSO metode katalis dan solar disiapkan dan karakteristiknya yang penting seperti viskositas, nilai kalor, flash point, fire point, dan sebagainya dievaluasi dan dibandingkan dengan solar. Hasilnya adalah tes kinerja mesin dalam waktu yang cukup lama menunjukkan bahwa campuran biodiesel dan solar menimbulkan endapan karbon yang lebih tinggi di dalam ruang bakar jika dibandingkan dengan solar murni. Oleh karena itu saringan bahan bakar, pompa, dan ruang bakar harus sering dibersihkan[1]. Tahun berikutnya, 2005, Ramadhas dkk meneliti tentang kinerja dan evaluasi emisi mesin diesel yang menggunakan bahan bakar metil ester minyak biji karet (RSOME) dan solar sebagai pembanding. Biodiesel diperoleh dengan metode katalis, proses dua tahap karena FFA tinggi (di atas $2,5 \%)$ yaitu esterifikasi katalis asam dan transesterifikasi katalis basa. Hasilnya menunjukkan bahwa jika campuran RSOME pada solar semakin rendah maka akan menghasilkan peningkatan efesiensi termal dan mengurangi konsumsi bahan bakar spesifik. Emisi gas buang menurun dengan kenaikan konsentrasi RSOME[2]. Di tahun yang sama, Pradeep dkk juga melakukan penelitian evaluasi kinerja, emisi, dan parameter pembakaran mesin diesel yang menggunakan bahan bakar biodiesel biji karet dan campurannya. Biodiesel yang dipakai diproduksi dengan metode katalis. Hasilnya menunjukkan bahwa B-100 menghasilkan efesiensi termal lebih rendah karena viskositasnya lebih tinggi dari pada solar, dan opasitasnya juga tinggi. Namun, campuran biodiesel dan solar menunjukkan bahwa efisiensi, opasitas, emisi CO dan HC dapat diterima[3]. Selanjutnya Edwin Geo dkk, 2009, melakukan investigasi eksperimen mempelajari karakteristik mesin diesel menggunakan RSO sebagai bahan bakar utama dengan dietil eter (DEE) sebagai pemicu pembakaran. DEE diinjeksikan ke dalam saluran masuk (intake manifold) selama langkah hisap, sedangkan RSO diinjeksikan secara langsung ke dalam silinder pada akhir langkah kompresi (23o sebelum TMA). Hasilnya menunjukkan bahwa efisiensi termal meningkat dari $26,5 \%$ menjadi 28,5\% dengan DEE diinjeksikan pada laju $200 \mathrm{~g} / \mathrm{jam}$. Opasitas berkurang secara signifikan dari 6,1 menjadi 4 BSU (Bosch Smoke Unit)[4]. Varuvel E.G. dkk, 2008, menggunakan RSO, RSOME, dan solar sebagai pembanding. Hasil penelitian menunjukkan bahwa fase pembakaran RSOME lebih intensif dari pada RSO karena keterlambatan pembakaran lebih rendah, durasi pengapian menurun, dan efisiensi termal lebih tinggi. Dengan menggunakan RSO menghasilkan efesiensi termal 26,53\%, dengan RSOME 27,89\%, sedangkan dengan solar $29,93 \%$ pada beban penuh. Tekanan puncak meningkat 2,3 bar untuk RSOME dibandingkan dengan RSO. Dalam kasus RSOME, emisi gas buang seperti $\mathrm{CO}, \mathrm{HC}$, dan opasitas menurun jika dibandingkan dengan RSO[5]. Varuvel E.G, dkk di tahun yang sama juga melakukan penelitian operasi ganda bahan bakar RSO dan RSOME dengan hidrogen dimasukkan ke dalam intake manifold. RSO, RSOME, dan solar digunakan sebagai bahan bakar utama. Pemakaian hydrogen dengan kwantitas bervariasi terhadap RSO dan RSOME menghasilkan efisiensi termal lebih tinggi dan penurunan emisi secara signifikan. Diperoleh efisiensi termal maksimum 28,12\%, 29,26\% dan $31,62 \%$ dengan RSO, RSOME dan solar pada kwantitas hydrogen $8,39 \%, 8,73 \%$, dan $10,1 \%$ masing-masing. Penurunan opasitas dari 5,5 menjadi 3,5 BSU dengan RSOME dan untuk RSO dari 6,1 menjadi 3,8 BSU pada efisiensi maksimum[6]. Semua proses produksi biodiesel tersebut di atas menggunakan metode katalis. Di Indonesia, pada umumnya juga menggunakan metode katalis.

Pengembangan proses produksi biodiesel biji karet metode non-katalis superheated metanol tekanan atmosfir serta tranesterifikasi berlangsung pada sebuah bubble column reactor (BCR) telah dilaporkan. Namun, hasil pengujian berdasarkan 
standard Forum Biodiesel Indonesia (FBI) 2005 menunjukkan bahwa residu karbon mikro biodiesel biji karet masih cukup tinggi di atas standard[7]. Jika biodiesel dari bahan nabati ini dipergunakan sebagai bahan bakar pada mesin diesel maka harus dicampur dengan solar pada tingkat perbandingan tertentu sehingga dapat memperkecil masalah utama tersebut di atas[1,2,3,5].

\section{METODE PENELITIAN}

\section{Bahan Bakar}

Bahan bakar yang dipergunakan pada mesin diesel adalah B-5, B-10, B-15, dan B-20, sedangkan solar murni (B-0) sebagai pembanding. Kwalitas biodiesel (B-100) dari biji karet yang diproses dengan metode non-katalis ditunjukkan pada Tabel 1 . Biodiesel ini tanpa mengalami proses "degumming" maupun esterifikasi. Transesterifikasi dilakukan pada sebuah reaktor (bubble column reactor) dengan memompakan superheated methanol ke dalam reaktor yang berisi cairan minyak biji karet (RSO).

Tabel 1. Hasil Uji Kwalitas Biodiesel Biji Karet Metode Non-Katalis Dibandingkan Standar FBI Tahun 2005

\begin{tabular}{|c|c|c|c|c|c|c|}
\hline \multirow{3}{*}{ No. } & \multicolumn{5}{|c|}{ Kwalitas Biodiesel Menurut Standar FBI 2005} & \multirow{3}{*}{$\begin{array}{c}\text { B-100 }{ }^{[7]} \\
\text { (Biodiesel } \\
\text { Biji Karet) }\end{array}$} \\
\hline & \multirow[b]{2}{*}{ Sifat Kimia } & \multirow[b]{2}{*}{ Satuan } & \multicolumn{2}{|c|}{ Batasan } & \multirow{2}{*}{$\begin{array}{c}\text { Metode } \\
\text { Pengujian } \\
\text { ASTM }\end{array}$} & \\
\hline & & & Min & Mak & & \\
\hline 1. & $\begin{array}{l}\text { Densitas pada } \\
15^{\circ} \mathrm{C}\end{array}$ & $\mathrm{kg} / \mathrm{m}^{3}$ & 850 & 890 & D-1298 & 882 \\
\hline 2. & $\begin{array}{l}\text { Viskositas } \\
\text { Kinematik }\left(40^{\circ} \mathrm{C}\right)\end{array}$ & $\mathrm{cSt}$ & 2,3 & 6,0 & D-445 & 5,19 \\
\hline 3. & Angka Cetana & & 51 & - & D-613 & $47,5 *)$ \\
\hline 4. & $\begin{array}{l}\text { Titik Tuang (Pour } \\
\text { Point) }\end{array}$ & ${ }^{\circ} \mathrm{C}$ & - & 18 & D-97 & -6 \\
\hline 5. & $\begin{array}{l}\text { Titik Nyala (Flash } \\
\text { Point) }\end{array}$ & ${ }^{\circ} \mathrm{C}$ & 100 & - & D-93 & 200 \\
\hline 6. & $\begin{array}{l}\text { Korosi Lempeng } \\
\text { Tembaga }(3 \text { jam } \\
\left.\text { pada } 50^{\circ} \mathrm{C}\right)\end{array}$ & No. ASTM & - & No.3 & D-130 & No.1.b \\
\hline 7. & $\begin{array}{l}\text { Residu Karbon } \\
\text { Mikro }\end{array}$ & $\%$ massa & & & & \\
\hline & $\begin{array}{l}\text { - dalam contoh } \\
\text { asli }\end{array}$ & & - & 0,05 & D-4530 & 0,126 \\
\hline & $\begin{array}{l}\text { - dalam } 10 \% \\
\text { ampas distilasi }\end{array}$ & & - & 0,3 & & 2,87 \\
\hline 8. & Air dan Sedimen & $\%$ volume & - & 0,05 & D-2709 & $\begin{array}{c}0 \\
0,01\end{array}$ \\
\hline & $\begin{array}{l}\text { Temperatur } \\
\text { Distilasi 90\% }\end{array}$ & ${ }^{\circ} \mathrm{C}$ & - & 360 & D-1160 & 347 \\
\hline 10. & Abu Tersulfatkan & $\%$ massa & - & 0,02 & D-874 & 0,01 \\
\hline 11. & Belerang & $\begin{array}{l}\text { ppm-m } \\
(\mathrm{mg} / \mathrm{kg})\end{array}$ & - & 100 & D-5453 & 0,72 \\
\hline 12. & Angka Asam & $\mathrm{mg}-\mathrm{KOH} / \mathrm{g}$ & - & 0,8 & D-664 & 0,01 \\
\hline 13. & Glyserol Bebas & $\%$ massa & - & 0,02 & D-6584 & - \\
\hline 14. & Glyserol Total & $\%$ massa & - & 0,24 & D-6584 & - \\
\hline
\end{tabular}

Catatan: Hasil uji tambahan a.l.:

Hasil uji nilai kalor metode ASTM D-240, LHV = 9184,43 kkal/kg. Hasil uji warna biodiesel standard ASTM D1500-98 yaitu 2.5, sedangkan persyaratannya maksimum 3,0 (memenuhi).

Rumus CCI $=454,74-1641,416 \mathrm{D}+774,74 \mathrm{D}^{2}-0,554 \mathrm{~B}+97,803$ $(\log \mathrm{B})^{2}$

$\mathrm{D}=$ densitas pada $15^{\circ} \mathrm{C}, \mathrm{g} / \mathrm{ml}$ metode test $\mathrm{D} 1298$ atau $\mathrm{D} 4052$,

$\mathrm{B}=$ mid boiling temperature ${ }^{\circ} \mathrm{C}$.

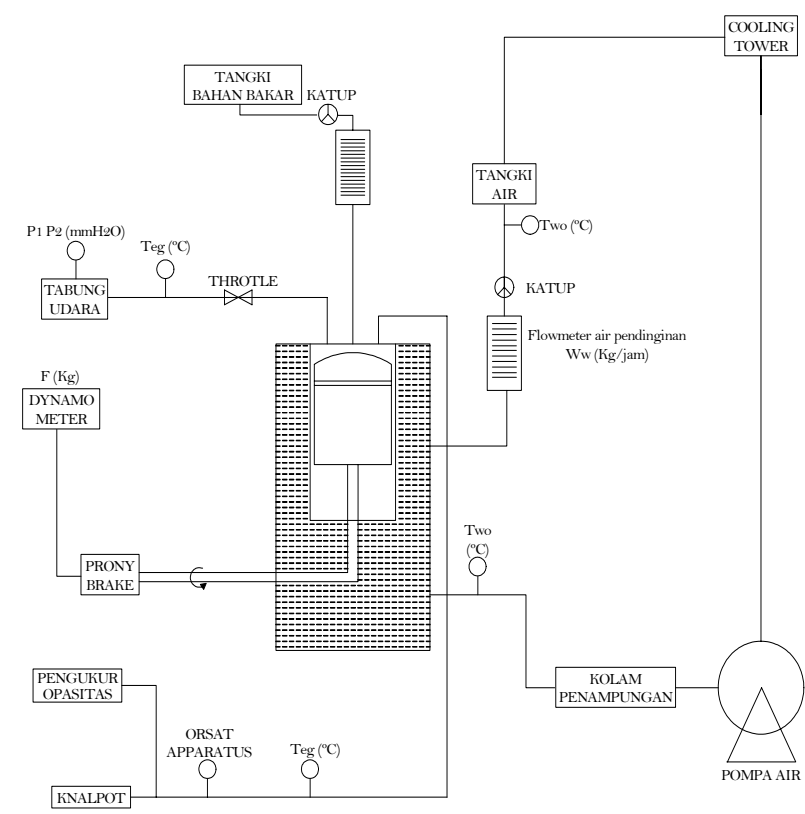

Gambar 1. Skema Pengujian Kinerja Mesin

Tidak terpenuhinya standar kandungan residu karbon mikro diduga karena pada metode nonkatalis tidak mengalami proses "degumming" sehingga lendir atau getah (gum) yang dikandung oleh RSO tidak bisa hilang. Getah atau lendir ini berpotensi menimbulkan kerak di dalam ruang bakar pada saat terjadinya pembakaran bahan bakar[1],[2]. Jika biodiesel biji karet metode non katalis ini (B-100 atau biodiesel murni) dipergunakan sebagai bahan bakar mesin diesel, maka harus dicampur dengan solar pada tingkat perbandingan tertentu misalnya B-5, B-10, B-15, atau B-20 sehingga kerak yang ditimbulkan di dalam ruang bakar menjadi lebih sedikit[7].

Biodiesel yang dihasilkan kemudian dicampur dengan solar dengan tingkat perbandingan tertentu yaitu B-5, B-10, B-15, dan B-20 (B-5 adalah campuran antara biodiesel 5\% dan solar 95\%, dst). Bahan bakar ini diujicobakan pada sebuah mesin diesel stasioner. Kinerja mesin serta emisi gas buang yang dihasilkan kemudian dibandingkan dengan mesin diesel memakai solar (B-0). Skema pengujian kinerja mesin ditunjukkan pada Gambar 1. Parameter yang akan diamati adalah: daya mesin, konsumsi bahan bakar spesifik, efisiensi termal, emisi gas buang yang dihasilkan terutama kandungan $\mathrm{CO}$, dan $\mathrm{CO}_{2}$, serta opasitas gas buang.

Spesifikasi motor diesel untuk percobaan:

- Merk: Nissan, Tokyo Co Ltd

- Model: DWE - 47-50-HS - AV

- Siklus: 4 langkah

- Jumlah silinder: 4 buah

- Volume langkah torak total: $2164 \mathrm{~cm}^{3}$

- Diameter silinder: $83 \mathrm{~mm}$ 
- Panjang langkah torak: $100 \mathrm{~mm}$

- Perbandingan kompresi: $22: 1$

- Bahan bakar: solar

- Pendingin: air

- Daya poros: $47 \mathrm{BHP} / 3200$ rpm

- Negara pembuat: JEPANG

Instrumen pengukur yang tersedia dalam instalasi percobaan motor bakar diantaranya adalah prony brake, rpm meter (tachometer), pengukur konsumsi bahan-bakar, Orsat appartus, pengukur kapasitas dan temperatur air pendingin, pengukur temperatur pada berbagai titik ukur dan lain-lain.

\section{HASIL DAN PEMBAHASAN}

\section{Daya Efektif}

Hubungan antara putaran dan daya efektif (Ne) pada pemakaian bahan bakar B-0 (solar); B-5; B-10; B-15; dan B-20 seperti terlihat pada Tabel 2 dan Gambar 2.

Dari Gambar 2 terlihat bahwa secara umum bentuk grafik untuk bahan bakar B-0 sampai B-20 hampir sama. Tampak pula bahwa semakin tinggi putaran maka daya efektif juga semakin tinggi, daya efektif maksimum diperoleh pada putaran mesin $\mathrm{n}=2550 \mathrm{rpm}$ sebesar 36,948 PS.

Tabel 2. Hubungan antara Putaran dan, Daya Efektif pada Berbagai Campuran Bahan Bakar

\begin{tabular}{cccccc}
\hline \multirow{2}{*}{$\begin{array}{c}\text { Putaran, n } \\
\text { (rpm) }\end{array}$} & $\begin{array}{c}\text { B-0 } \\
\text { (Solar) }\end{array}$ & B-5 & B-10 & B-15 & B-20 \\
\hline 1350 & 19,923 & 19,198 & 19,440 & 17,883 & 17,995 \\
1750 & 25,826 & 26,139 & 26,295 & 24,347 & 24,493 \\
2150 & 31,152 & 31,729 & 31,729 & 29,554 & 29,554 \\
2550 & 36,264 & 36,948 & $\mathbf{3 6 , 9 4 8}$ & 34,203 & 34,203 \\
2950 & 11,082 & 12,137 & 11,346 & 9,585 & 8,602 \\
\hline Rata-rata & 24,840 & 25,230 & 25,150 & 23,110 & 22,960 \\
\hline
\end{tabular}

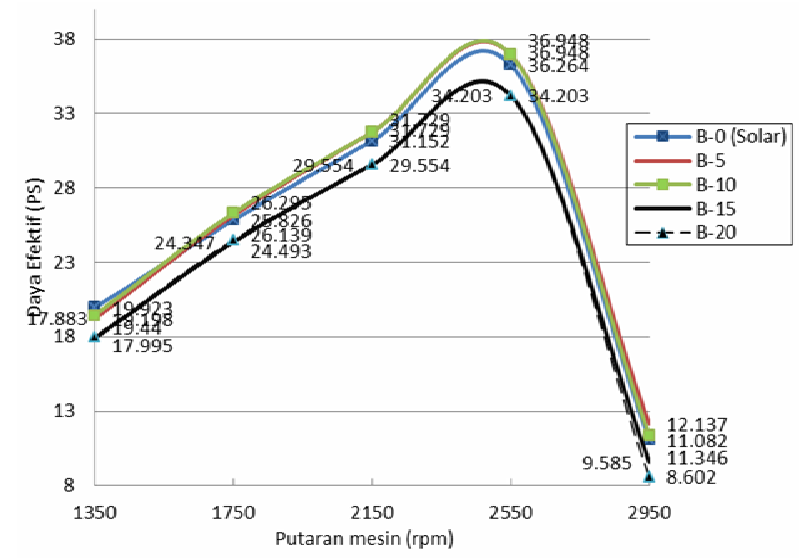

Gambar 2. Hubungan antara Putaran dan Daya Efektif
Pada putaran yang semakin tinggi dari 2550 maka daya efektif menurun karena kehilangan daya gesekan semakin besar. Grafik B-5 dan B-10 hampir berimpit, tetapi daya yang dihasilkan oleh B-5 pada putaran rendah lebih kecil dari pada B-10. Grafik B15 dan B-20 juga hampir berimpit tetapi pada putaran rendah daya yang dihasilkan oleh B-20 masih lebih tinggi dari pada B-15, namun pada putaran tinggi B-20 lebih kecil dari B-15. Grafik B-5 dan B-10 masih lebih tinggi dari pada B-15 dan B20. Grafik B-0 berada diantara grafik B-15 dan B-10. Jadi, daya mesin maksimum yang dihasilkan jika menggunakan bahan bakar B-10.

Jika kita bandingkan B-10 dengan solar murni (B-0), dari data pada Tabel 2 khusus pada putaran $2550 \mathrm{rpm}$ (kondisi optimum) tampak bahwa solar menghasilkan daya sebesar 36,264 PS sedangkan B10 menghasilkan daya 36,948 PS. Dengan demikian maka pemakaian B-10 mampu menaikkan daya mesin sebesar 1,8\% \{(dasar perhitungan \{36,948 36,264): 36,264$)\}$. Tetapi jika kita lihat nilai rataratanya antara putaran $1350 \mathrm{~s} / \mathrm{d} 2950 \mathrm{rpm}$, tampak bahwa bahan bakar B-10 dapat menghasilkan daya rata-rata sebesar 25,15 PS sedangkan solar 24,84 PS. Dengan demikian berarti bahwa secara ratarata, pemakaian bahan bakar B-10 mampu meningkatkan daya mesin sebesar 1,2\% [dasar perhitungan sebagai berikut: $(25,15-24,84): 24,84]$.

\section{Konsumsi Bahan Bakar Spesifik}

Hubungan antara pemakaian bahan bakar spesifik (specific fuel consumption) terhadap putaran mesin ditunjukkan pada Tabel 3 dan Gambar 3.

Pada pembahasan dimuka, telah diketahui bahwa daya maksimum diperoleh pada putaran $\mathrm{n}=$ 2.250 rpm untuk jenis bahan bakar B-10. Apabila kita lihat grafik pada Gambar 3, tampak bahwa konsumsi bahan bakar spesifik untuk B-0 sampai dengan B-15 cendrung hampir berimpit mulai putaran 1.350 sampai $2.550 \mathrm{rpm}$. Pada putaran $2.950 \mathrm{rpm}$ jelas ada perbedaan yaitu B-20 tertinggi dan B-5 terendah, sementara itu B-0 berada ditengah-tengah antara B-10 dan B-15. Khusus untuk B-10 pada putaran $2.550 \mathrm{rpm}$ pada daya maksimum memerlukan konsumsi bahan bakar spesifik $0,256 \mathrm{~kg} /(\mathrm{PS} . j \mathrm{jam})$.

Tabel 3. Kunsumsi Bahan Bakar Spesifik

\begin{tabular}{cccccc}
\hline \multirow{2}{*}{$\begin{array}{c}\text { Putaran } \\
\text { mesin (rpm) }\end{array}$} & \multicolumn{5}{c}{$\begin{array}{c}\text { Konsumsi Bahan Bakar Spesifik, sfc } \\
(\mathrm{kg} /(\mathrm{PS} . j \mathrm{jam})\end{array}$} \\
\cline { 2 - 6 } & $\begin{array}{c}\text { B-0 } \\
\text { (Solar) }\end{array}$ & B-5 & B-10 & B-15 & B-20 \\
\hline 1350 & 0,245 & 0,256 & 0,256 & 0,263 & 0,258 \\
1750 & 0,265 & 0,253 & 0,253 & 0,252 & 0,254 \\
2150 & 0,269 & 0,258 & 0,259 & 0,254 & 0,262 \\
2550 & 0,256 & 0,256 & $\mathbf{0 , 2 5 6}$ & 0,259 & 0,253 \\
2950 & 0,471 & 0,446 & 0,465 & 0,497 & 0,558 \\
\hline Rata-rata & 0,300 & 0,290 & 0,290 & 0,300 & 0,310 \\
\hline
\end{tabular}




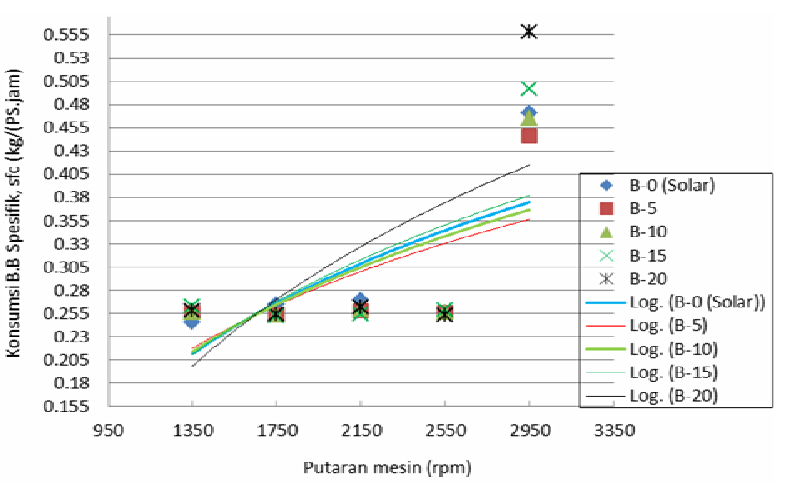

Gambar 3. Pengaruh Putaran Mesin pada Konsumsi Bahan Bakar Spesifik

Konsumsi ini hampir sama dengan untuk putaran mulai $1.350 \mathrm{rpm}$ sampai dengan $2.550 \mathrm{rpm}$. Jika kita bandingkan B-10 dengan solar murni (B0 ), dari data pada Tabel 3 khusus pada putaran $2550 \mathrm{rpm}$ (kondisi optimum) tampak bahwa B-10 memerlukan bahan bakar spesifik sama dengan B-0 (solar) yaitu 0,256 kg/(PS.jam). Tetapi jika kita lihat nilai rata-ratanya antara putaran 1350 s/d 2950 rpm, tampak bahwa bahan bakar B-10 dapat menghemat pemakaian bahan bakar spesifik sebesar 3,3\% [dasar perhitungan sebagai berikut: $(0,29-0,30): 0,30]$.

\section{Efisiensi Termal}

Hubungan antara jenis bahan bakar dan putaran mesin terhadap efisiensi termal ditunjukkan pada Tabel 4 dan Gambar 4.

Dari grafik pada Gambar 4, tampak bahwa pada putaran antara $1.350 \mathrm{rpm}$ sampai $1.750 \mathrm{rpm}$ terjadi kenaikan efisiensi termal untuk semua jenis bahan bakar (B-0 s/d B-20), tetapi setelah putaran 1750 rpm terjadi penurunan efisiensi termal sampai putaran 2950 rpm. Penurunan efisiensi ini akibat dari semakin banyaknya panas yang hilang melalui gas buang karena putaraan semakin tinggi. Grafik B-5, B-10, B-15, maupun B-20 berada di atas grafik B-0 (solar murni), ini berarti memiliki efisiensi termal lebih tinggi dari pada solar murni. Pada umumnya, persoalan utama yang dihadapi oleh bahan bakar fosil (BBM) adalah rendahnya efisiensi termal.

Tabel 4. Hubungan antara Jenis Bahan Bakar dan Putaran Mesin pada Efisiensi Termal Indikatif

\begin{tabular}{cccccc}
\hline \multirow{2}{*}{$\begin{array}{c}\text { Putaran } \\
\text { mesin (rpm) }\end{array}$} & \multicolumn{5}{c}{ Efisiensi termal indikatif, $\eta_{\mathrm{i}}(\%)$} \\
\cline { 2 - 6 } (Solar) & B-5 & B-10 & B-15 & B-20 \\
\hline 1350 & 45,27 & 58,20 & 59,73 & 66,92 & 63,65 \\
1750 & 57,40 & 56,04 & 58,53 & 60,40 & 59,58 \\
2150 & 58,13 & 56,05 & 58,90 & 60,09 & 60,23 \\
2550 & 57,07 & 55,44 & 58,45 & 59,29 & 55,81 \\
2950 & 24,64 & 24,44 & 18,07 & 19,10 & 16,25 \\
\hline Rata-rata & 48,50 & 50,03 & 50,73 & 53,16 & 51,10 \\
\hline
\end{tabular}

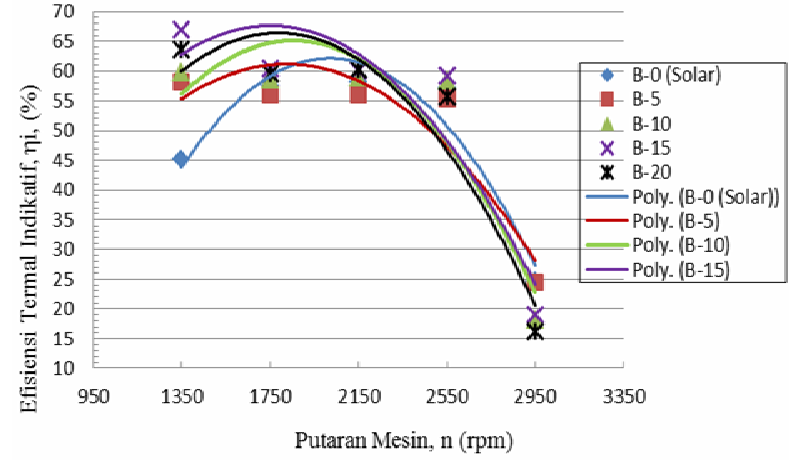

Gambar 4. Hubungan antara Putaran Mesin dan Efisiensi Termal Indikatif

Karena B-5 s/d B-20 mampu menaikkan efisiensi termal maka sangat cocok dipergunakan sebagai bahan bakar alternatif.

Jika kita bandingkan B-10 dengan solar murni (B-0), dari data pada Tabel 4 khusus pada putaran 2550 rpm (kondisi optimum), tampak bahwa solar menghasilkan efisiensi termal sebesar 57,07\% sedangkan B-10 menghasilkan efisiensi termal 58,45\%. Dengan demikian maka pemakaian B-10 mampu menaikkan efisiensi termal sebesar 2,4\% [dasar perhitungan sebagai berikut: $(58,45-57,07)$ : 57,07)]. Tetapi jika kita lihat nilai rata-ratanya, antara putaran $1350 \mathrm{~s} / \mathrm{d} 2950 \mathrm{rpm}$, tampak bahwa bahan bakar B-10 dapat menghasilkan kenaikan efisiensi termal sebesar 4,6\% [dasar perhitungan sebagai berikut: $(50,73-48,50): 48,50]$.

\section{Analisa Gas Buang}

\section{$\underline{\text { Opasitas Gas Buang }}$}

Tabel 5 dan Gambar 5 menunjukkan hubungan antara putaran dengan opasitas.

Pada Tabel 5 dan Gambar 5 tampak jelas bahwa semakin tinggi putaran mesin maka opasitas gas buang semakin naik untuk semua jenis bahan bakar baik dari bahan bakar B-5 s/d B-20. Pada putaran 2550 rpm, B-20 menghasilkan opasitas terbesar kemudian disusul oleh B-15, B-5, kemudian terkecil oleh B-10. Opasitas gas buang berada pada kisaran antara 57,82 s/d 62,44\% HSU; opasitas terbesar dihasilkan oleh B-20 yaitu 62,44\%. Namun jika kita lihat pada peraturan Menteri Negara Lingkungan Hidup no.5/2006 terlihat bahwa batas maksimum opasitas yang diijinkan untuk motor diesel tahun pembuatan dibawah tahun 2010 yaitu $70 \%$ HSU. Ini berarti opasitas gas buang yang dihasilkan oleh bahan bakar biodiesel biji karet sampai B-20 masih memenuhi syarat. Semakin gelap warna opasitas maka hal ini berarti opasitas semakin tinggi. 
Tabel 5. Opasitas Gas Buang pada Berbagai Putaran Mesin

\begin{tabular}{ccccc}
\hline \multirow{2}{*}{$\begin{array}{c}\text { Putaran } \\
\text { mesin } \\
(\mathrm{rpm})\end{array}$} & B-5 & B-10 & B-15 & B-20 \\
\cline { 2 - 5 } & & & \\
\hline 1350 & 55,0 & 55,0 & 55,0 & 55,0 \\
1750 & 55,6 & 58,3 & 58,6 & 62,2 \\
2150 & 59,3 & 58,5 & 60,0 & 64,2 \\
2550 & 59,6 & $\mathbf{5 8 , 6}$ & 60,2 & 65,3 \\
2950 & 59,6 & 58,7 & 61,0 & 65,5 \\
\hline Rata-rata & 57,82 & 57,82 & 58,96 & 62,44 \\
\hline
\end{tabular}

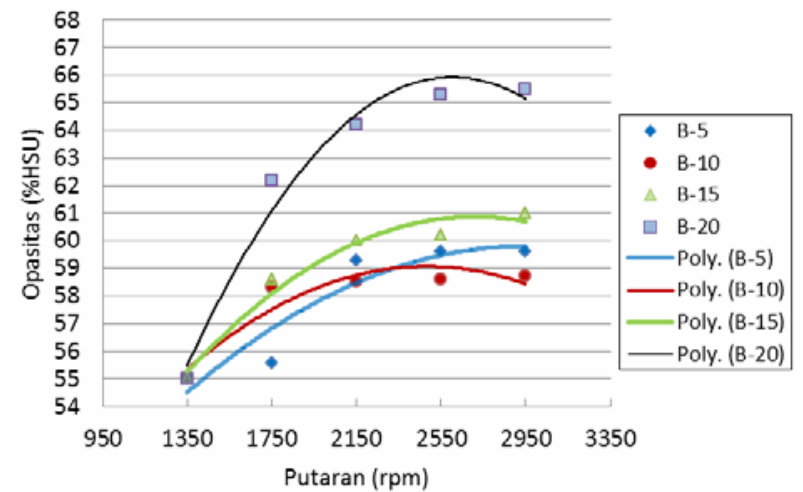

Gambar 5. Pengaruh Putaran Mesin pada Opasitas Gas Buang

\section{Kandungan CO Gas Buang}

Kandungan CO yang tinggi pada gas buang akan dapat merusak kesehatan dan merusak lapisan ozon. Hubungan antara putaran mesin terhadap kandungan $\mathrm{CO}$ gas buang diperlihatkan pada Tabel 6 dan Gambar 6 .

Kalau kita lihat kandungan gas CO pada gas buang untuk setiap jenis bahan bakar, pada Tabel 6 tampak bahwa pada putaran $2550 \mathrm{rpm}$ bahan bakar B-10 menghasilkan kadar CO terkecil yaitu 0,4\%; sedangkan bahan bakar B-20 kadar CO nya terbesar yaitu 2,0\%. Dari Gambar 6, terlihat pula bahwa semakin tinggi putaran, kecendrungan grafik B-0 semakin meninggi yang menandakan bahwa kadar CO semakin meningkat. Demikian juga grafik B-5 dan B-15 walaupun masih berada di bawah grafik B-0. Grafik B-10 dan B-20 sangat berbeda dengan ketiga grafik tersebut yaitu semakin tinggi putaran mesin maka kecendrungan kadar CO semakin rendah tetapi grafik B-10 berada di bawah grafik B-20 yang berarti bahwa kadar CO yang dihasilkan oleh B-10 lebih rendah dari pada B20. Dengan demikian grafik B-10 merupakan grafik terbaik.

Jika kita bandingkan B-10 dengan solar murni (B-0) dari data pada Tabel 6, khusus pada putaran 2550 rpm (kondisi optimum) tampak bahwa solar menghasilkan kadar $\mathrm{CO}$ gas buang sebesar 2,0\% sedangkan B-10 menghasilkan kadar CO pada gas buang sebesar $0,4 \%$.
Tabel 6. Kandungan CO Gas Buang (\%) pada Berbagai Putaran Mesin

\begin{tabular}{cccccc}
\hline Putaran & \multicolumn{5}{c}{ Kandungan CO Gas Buang (\%) } \\
\cline { 2 - 6 } $\begin{array}{c}\text { Mesin, n } \\
\text { (rpm) }\end{array}$ & $\begin{array}{c}\text { B-0 } \\
\text { (solar) }\end{array}$ & B-5 & B-10 & B-15 & B-20 \\
\hline 1350 & 2,0 & 1,2 & 2,0 & 1,2 & 2,0 \\
1750 & 0,4 & 2,0 & 1,2 & 2,0 & 4,0 \\
2150 & 4,0 & 0,4 & 1,6 & 1,2 & 2,0 \\
2550 & 2,0 & 1,6 & $\mathbf{0 , 4}$ & 0,8 & 2,0 \\
2950 & 2,6 & 3,2 & 1,6 & 3,2 & 0,4 \\
\hline Rata-rata & 2,4 & 1,68 & 1,36 & 1,68 & 2,08 \\
\hline
\end{tabular}

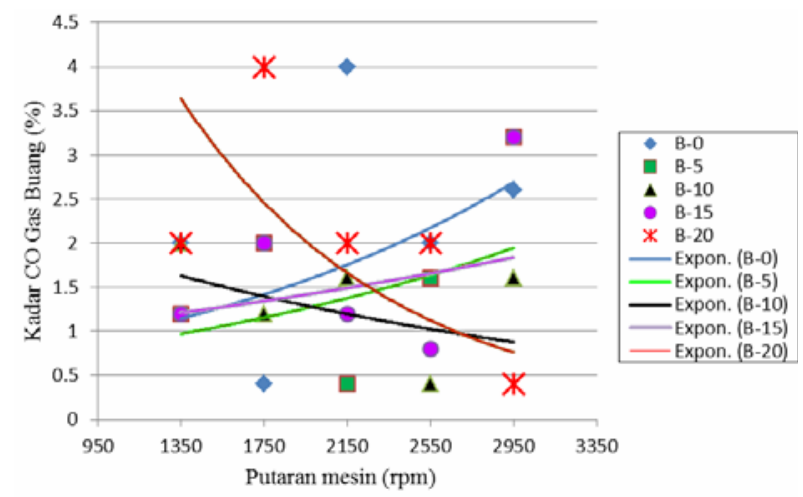

Gambar 6. Pengaruh Putaran Mesin pada Kadar CO Gas Buang Bahan Bakar

Dengan demikian maka pemakaian B-10 mampu menurunkan kadar CO gas buang sebesar 80\% [dasar perhitungan sebagai berikut: $(0,4-2,0): 2,0)$ ]. Tetapi jika kita lihat nilai rata-ratanya antara putaran 1350 s/d $2950 \mathrm{rpm}$, tampak bahwa bahan bakar B-10 dapat menurunkan kadar CO gas buang sebesar 43,3\% [dasar perhitungan sebagai berikut: $(1,36-2,4): 2,4]$.

Kadar CO yang tinggi dalam gas buang mempunyai dampak buruk terhadap atmosfir yaitu dapat merusak lapisan ozon $\left(\mathrm{O}_{3}\right)$ dan akan terbentuk $\mathrm{CO}_{2}$ sesuai reaksi: $\mathrm{CO}+\mathrm{O}_{3} \rightarrow \mathrm{CO}_{2}+\mathrm{O}_{2}$. Jika ozon rusak, maka sinar matahari akan langsung menerpa bumi. Terjadi pemanasan global. Kutub es cendrung akan mencair dan dikhawatirkan banyak pulau yang tenggelam. Disamping itu pula akan terjadi abrasi atau erosi (pengikisan) oleh air laut karena volume air laut bertambah sehingga luas daratan semakin hari semakin berkurang.

\section{$\underline{\text { Kandungan } \mathrm{CO}_{2}}$}

Tabel 7 menunjukkan kandungan $\mathrm{CO}_{2}$ pada gas buang, sedangkan Gambar 7 menunjukkan grafik pengaruh putaran mesin terhadap kandungan $\mathrm{CO}_{2}$ gas buang.

Dari Gambar 7 terlihat bahwa grafik bahan bakar solar (B-0) paling atas. Ini berarti bahwa bahan bakar B-5, B-10, B-15, maupun B-20 mampu menghasilkan $\mathrm{CO}_{2}$ yang lebih rendah dari pada solar. 
Tabel 7. Kandungan $\mathrm{CO}_{2}$ Gas Buang pada Berbagai Putaran Mesin

\begin{tabular}{cccccc}
\hline \multirow{2}{*}{$\begin{array}{c}\text { Putaran } \\
\text { mesin } \\
(\mathrm{rpm})\end{array}$} & \multicolumn{5}{c}{ Kandungan $\mathrm{CO}_{2}$ Gas Buang (\%) } \\
\cline { 2 - 6 } & B-0 (Solar) & B-5 & B-10 & B-15 & B-20 \\
\hline 1350 & 8.0 & 4.8 & 2.0 & 3.2 & 2.0 \\
1750 & 8.0 & 6.0 & 4.0 & 5.2 & 4.0 \\
2150 & 4.0 & 4.0 & 4.8 & 4.8 & 4.0 \\
2550 & 8.0 & 4.4 & 3.6 & 4.4 & 7.2 \\
2950 & 7.0 & 4.4 & 3.2 & 6.0 & 6.8 \\
\hline Rata-rata & 7,0 & 4,72 & 3,52 & 4,72 & 4,80 \\
\hline
\end{tabular}

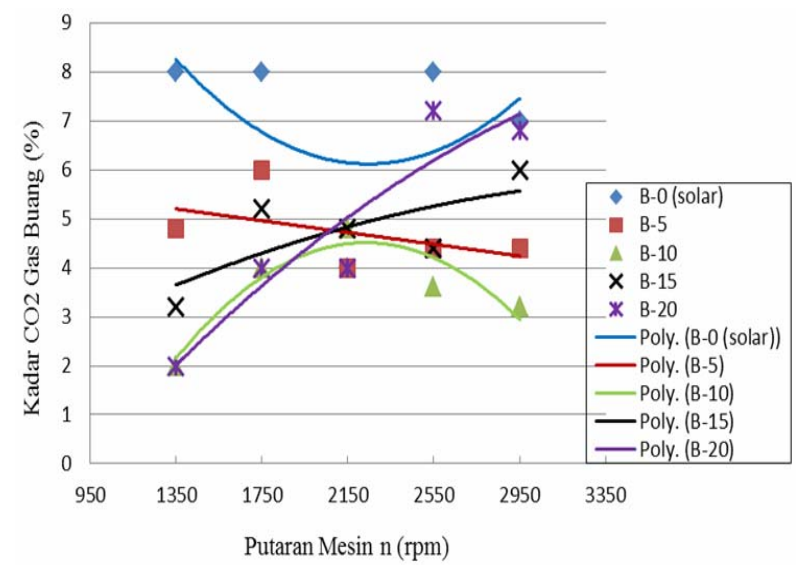

Gambar 7. Hubungan antara Putaran Mesin dan Kadar CO2 Gas Buang

Dengan demikian dapat mengurangi efek rumah kaca. Kandungan $\mathrm{CO}_{2}$ yang berlebih pada gas buang akan menimbulkan efek rumah kaca. Untuk B-5, semakin tinggi putaran maka $\mathrm{CO}_{2}$ yang terbentuk cendrung semakin rendah tapi landai. Bahan bakar B-10 grafiknya paling rendah, hal ini berarti bahwa kadar $\mathrm{CO}_{2}$ paling rendah. Untuk B15, semakin tinggi putaran maka kecendrungan terbentuknya $\mathrm{CO}_{2}$ semakin tinggi pula. Bahan bakar B-20 mempunyai kenaikan yang paling tajam diantara B-5 s/d B-20.

Jika kita bandingkan B-10 dengan solar murni (B-0) dari data pada Tabel 7 khusus pada putaran 2550 rpm (kondisi optimum), tampak bahwa solar menghasilkan kadar $\mathrm{CO}_{2}$ yang dikandung oleh gas buang sebesar 8,0\% sedangkan B-10 menghasilkan kadar $\mathrm{CO}_{2}$ pada gas buang sebesar 3,6\%. Dengan demikian maka pemakaian B-10 mampu menurunkan kadar $\mathrm{CO}_{2}$ gas buang sebesar 55,0\% [dasar perhitungan sebagai berikut: $(3,6-8,0): 8,0)]$. Tetapi jika kita lihat nilai rata-ratanya, antara putaran $1350 \mathrm{~s} / \mathrm{d} 2950 \mathrm{rpm}$, tampak bahwa bahan bakar B10 dapat menurunkan kadar $\mathrm{CO}_{2}$ gas buang sebesar $49,7 \%$ [dasar perhitungan sebagai berikut: $(3,52-$ 7,0): 7,0].

Rekapitulasi karakteristik kinerja mesin diesel stasioner untuk berbagai jenis bahan bakar pada kondisi optimum (putaran mesin $\mathrm{n}=2.550 \mathrm{rpm}$ ) ditunjukkan pada Tabel 8.
Tabel 8. Rekapitulasi Karakteristik Kinerja Mesin pada Kondisi Optimum ( $=2.550 \mathrm{rpm})$

\begin{tabular}{|c|c|c|c|c|c|c|c|c|}
\hline $\begin{array}{c}\text { Jenis } \\
\text { BB }\end{array}$ & $\begin{array}{l}\text { LHV } \\
\text { (kkal/ } \\
\text { kg) }\end{array}$ & $\begin{array}{l}\text { Densi- } \\
\text { tas } \\
(\mathrm{g} / \mathrm{ml})\end{array}$ & $\begin{array}{c}\mathrm{Ne} \\
\text { (PS) }\end{array}$ & $\begin{array}{c}\mathrm{SFC}_{\mathrm{e}} \\
\text { (kg/ } \\
\text { (PS.jam) }\end{array}$ & $\begin{array}{c}\eta I \\
(\%)\end{array}$ & $\begin{array}{c}\text { CO } \\
\text { (\%vol) }\end{array}$ & $\begin{array}{c}\mathrm{CO}_{2} \\
\text { (\%vol) }\end{array}$ & $\begin{array}{c}\text { Opasitas } \\
\text { (\%HSU) }\end{array}$ \\
\hline $\begin{array}{c}\text { B-0 } \\
\text { (solar) }\end{array}$ & 10.500 & 0,835 & 36,26 & 0,256 & 57.06 & 2,0 & 8,0 & - \\
\hline B-5 & 10.642 & 0,846 & 36,95 & 0,256 & 55.43 & 1,6 & 4,4 & 59,6 \\
\hline B-10 & 10.738 & 0,848 & 36,95 & 0,256 & 58.44 & 0,4 & 3,6 & 58,6 \\
\hline B-15 & 10.858 & 0,852 & 34,20 & 0,259 & 59.28 & 0,8 & 4,4 & 60,2 \\
\hline B-20 & 10.473 & 0,853 & 34,20 & 0,253 & 55.81 & 2,0 & 7,2 & 65,3 \\
\hline $\begin{array}{c}\text { B-100 } \\
\text { biodiesel }\end{array}$ & 9.184 & 0,882 & & Vis & itas & em & $5,19 \mathrm{cS}$ & \\
\hline
\end{tabular}

murni)

$\eta_{\mathrm{i}}=$ efisiensi termal indikatif (\%).

$\mathrm{CO} \Rightarrow$ merusak ozon; $\mathrm{CO}_{2} \Rightarrow$ efek rumah kaca; Opasitas $\Rightarrow$ kepekatan gas buang

Dari Tabel 8 terlihat bahwa bahan bakar B-10 mampu menghasilkan daya terbesar yaitu 36,95 PS dengan pemakaian bahan bakar spesifik terendah 0,256 kg/(PS.jam) serta kandungan CO terkecil 0,4\% dan $\mathrm{CO}_{2}$ terkecil pula yaitu $58,6 \%$ termasuk ramah lingkungan. Nilai kalor B-10 adalah 10.738,19 kal/gram lebih tinggi dari pada solar yang mempunyai nilai kalor $10.500 \mathrm{kal} / \mathrm{gram}$. Juga terlihat bahwa daya mesin yang menggunakan bahan bakar B-10 lebih tinggi dari pada yang menggunakan bahan bakar murni solar (B-0) sekitar 1,8\%. Tidak terjadi detonasi, dan tidak perlu mengubah konstruksi mesin.

Dari data pada Tabel 8, jika kita bandingkan antara penggunaan B-10 dan B-0 (solar murni) terlihat bahwa B-10 menghasilkan daya lebih besar 0,69 PS dari pada solar murni, kadar CO maupun $\mathrm{CO}_{2}$ gas buang lebih rendah sehingga B-10 lebih ramah lingkungan. B-10 menghasilkan daya efektif lebih tinggi mungkin juga disebabkan oleh nilai kalor bahan bakar memang lebih tinggi dimana solar mempunyai nilai kalor $10.500 \mathrm{kcal} / \mathrm{kg}$ sedangkan B-10 nilai kalornya $10.738 \mathrm{kcal} / \mathrm{kg}$. Efisiensi termal indikatif $\left(\eta_{i}\right)$ juga tampak lebih tinggi dimana solar mempunyai efisiensi termal indikatif $57,06 \%$ sedangkan B-10 58,44\%.

Jika kita bandingkan khususnya kadar CO gas buang pada Tabel 8 tersebut di atas dengan standar emisi mesin yaitu standard URO-2 (Emission Standards for Light-Duty Diesel Engines) terlihat bahwa kadar CO masih memenuhi syarat karena URO-2 mensyaratkan kadar CO maksimum 4 $\mathrm{g} / \mathrm{kWh}$ (ekivalen dengan $5 \% \mathrm{CO}$ untuk daya mesin $47 \mathrm{BHP})$.

\section{KESIMPULAN}

Berdasarkan analisis data tersebut di atas dapat disimpulkan bahwa bahan bakar biodiesel biji karet B-10 menghasilkan kinerja mesin terbaik pada putaran $2550 \mathrm{rpm}$. Pada putaran ini diperoleh daya maksimum 36,95 PS, konsumsi bahan bakar 
spesifik terendah 0,256 kg/(PS.jam), efisiensi termal indikatif cukup tinggi yaitu 58,44\%, kandungan CO terkecil 0,4\%, dan opasitas gas buang 58,6 \% HSU memenuhi Peraturan Menteri Negara Lingkungan Hidup Nomor 5 tahun 2006, dan tidak perlu memodifikasi mesin.

Jika kita bandingkan antara solar (B-0) dengan B-10, terlihat dengan jelas bahwa B-10 lebih baik dari pada solar karena pada kondisi optimum (putaran $2550 \mathrm{rpm}$ ) B-10 mampu menaikkan daya mesin sebesar $1,8 \%$ walaupun konsumsi bahan bakar spesifik sama yaitu 0,256 kg/(PS.jam), efisiensi termal naik sebesar 2,4\%, kadar CO gas buang turun $80 \%$, kadar $\mathrm{CO}_{2}$ juga turun sebesar $55 \%$.

\section{DAFTAR PUSTAKA}

1. Ramadhas, AS., Jayaraj, S., Muraleedharan,C., Characterization and Effect of Using Rubber Seed Oil as Fuel in the Compression Ignition Engines, International Journal of Renewable Energy, Vol.30, Issue 5, Calicut 673 601, India, pages 795-803, April 2005.

2. Ramadhas, A.S., Mulareedharan, C., Jayaraj, S., Performance and Emission Evaluation of a Diesel Engine Fueled with Methyl Esters of Rubber Seed Oil, International Journal of Renewable Energy, 30, 1789-1800, 2005.
3. Pradeep V and Sharma R.P., Evaluation of Performance, Emission and Combustion Parameters of a CI Engine Fueled with Biodiesel from Rubber Seed Oil and its Blends, SAE Paper, India, 26-353, 2005.

4. Edwin Geo, V., Nagarajan, G., Kamalakannan, J., Nagalingam, B., Experimental Investigations To Study the Characteristics of Rubber-Seed-OilFueled Diesel Engine Supplemented with Diethyl Ether, Energy and Fuels, American Chemical Society, 23, 533-538, 2009.

5. Varuvel, E.G., Nagarajan, G., Nagalingam, B., A Comparative Combustion Analysis of Rubber Seed Oil and its Methyl Ester in a D.I Diesel Engine, SAE World Congress.\& Exhibition, Technical Papers, Detroit, No: 2008-01-1386, 2008.

6. Varuvel, E.G., Nagarajan, G., Nagalingam, B., Studies on Dual Fuel Operation of Rubber Seed Oil and its Biodiesel with Hydrogen as the Inducted Fuel, International Journal of Hydrogen Energy, vol. 33, issues 21, pages 6357-6367, 2008.

7. I Wayan Susila, Pengembangan Proses Produksi Biodiesel Biji Karet Matode Non-Katalis Superheated Methanol Tekanan Atmosfir, Journal Nasional Terakreditasi Teknik Mesin., Universitas Petra Surabaya, vol 11/No.2/2009, hal $115-124,2009$. 